Dept. of Anatomy and Histology, Fac. Vet. Med., Assiut University.

Head of Dept. Prof. Dr. A. Hifny.

\title{
AN ELECTRON MICROSCOPIC STUDY OF ESOPHAGEAL EPITHELIUM IN THE FOWL (GALLUS GALLUS DOMESTICUS)
}

(With 5 Fig.)

By

YOUSRIA A. ABDEL-RAHMAN

(Received at $30 / 6 / 1993$ )

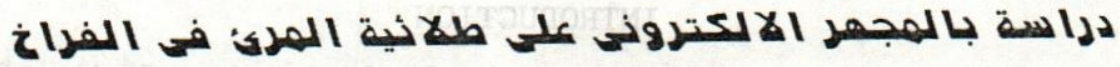

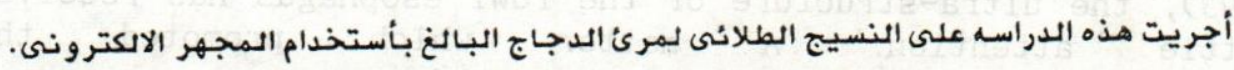

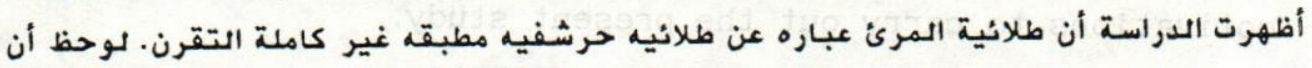
الخلايـا القتاعديه وكذلك الطبقات السفلى من الخلايـا الشـائكه متشـابهة التركيب. شوهدت الحبيبـات

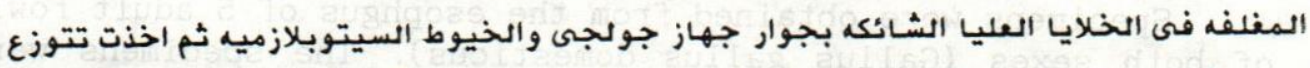
فى سيتو بلازم خلايا الطبقات العليا ـو وجد أن الخيو ط السيتو بلازميه لهذه الطلائيه تختكف من حيث الكميه والتوزيع · وقد شوهدت القطيرات الدهنيه فنى كل الطبقات. أما الحبيبات الهلاميه الكير اتينيه فوجدت فى الطبقات المحببه وكذكك القرنيه. وقد أفهرت الدراسـ أيفك أن الطبقه القرنيه قد أستبدلت عضياتها بالخيوط السيتوبلازميه التى تظهر في مورة حزم صفير ه أو خيوط دقيقه. 


\section{SUMMARY}

This study was carried out on the lining epithelium of the esophagus of 5 adult fowls. The ultrastructural study revealed that this epithelium is of the stratified squamous type which is incompletely keratinized. The basal and the deep spinous cells are structurally similar. The membrane-coating granules (MCG) are firstly appeared in the upper spinous cells in association with Golgi complex and cytoplasmic filaments, then after they are scattered in the cytoplasm of the upper cell layers. The cytoplasmic filaments vary greatly in their distribution throughout the epithelium. Fat droplets were observed in all strata, while the keratohyalin granules are found in both stratum granulosum and stratum corneum. In the latter the organelles are replaced with variable electron dense filaments and some cells retain their nuclei.

\section{INTRODUCTION}

Although the histomorphological features of the lining epithelium of fowl esophagus has been examined (CALHOUN, 1954; BRADLEY and GRAHAME, 1960; KROLLING, 1960; HODGES, 1974; MCLELLAND, 1975; SCHRODER, 1985; MICHEL et al., 1986; BANKS, 1993), the ultra-structure of the fowl esophagus has received little attention. A matter which promoted the motivations to carry out the present study.

MATERAL and METHODS

Specimens were obtained from the esophgus of 5 adult fowls of both sexes (Gallus gallus domesticus). The specimens were firstly washed with salin solution, then directly fixed in $4 \%$ glutaraldehyde in 0.1 cacodylate buffer ( $\mathrm{pH} 7.2)$ for 2-4 hours, followed by postfixation for 2 hours in $1 \%$ osmium tetroxide. then after the specimens were dehydrated through ascending grades of aceton, embedded in Durcupan and sectioned by using LKB ultratome. Uranyl acetate and citrate were used for staining the sections which were then examined and photographed in JEOL $100 \mathrm{C} X$ II electron microscope.

\section{RESULTS}

The lining epithelium of the esophgus fowl, being of the partially keratinized stratified oquamous type, consists of 26-30 layers of epithelial cells. Four strata could be

Assiut. Vod. Meu. J. v1._29, No. 58, July 1993. 
distinguished: Stratum basale, Stratum Intermedium (spinosum), Stratum granulosum and Stratum corneum.

1. Stratum basale (Fig, $1 \mathrm{a}, \mathrm{b}$ ):

The basal cells, being elongated or ovoid in shape, lie perpendicular to the basal lamina. They are connected to the neighbouring and overlying cells by few desmosomes (D) and interdigitations through few short cytoplasmic processes which extend into a very narrow intercellular space. The basal cytoplasm of these cells show few and short projections which are followed by infolding of the basal lamina (BL). They are connected together by numerous hemidesmosomes (HD).

The basal cells have large oval or ovoid nuclei (N). They have shallow and/or deep indentations. Few amount of marginal or islands heterochromatin was observed. They contain 1-2 nucleolei. The distinct nuclear membrane is traversed by numerous pores $(P)$.

The cytoplasm of the basal cells has moderate electron density. It contains moderate amount of free ribosomes which are distributed singly or in groups. Few ribosomes are attached to the outer nuclear membrane. Variable amounts of electrondense cytoplasmic filaments (F) were observed. They occurin the form of bundles scattered allover the cytoplasm and others are associated with the desmosomes and hemidesmosomes. Mitochondria (M) appear in a moderate number, they may be rounded or oval in shape and are distributed mainly around the nucleus. The rough endoplasmic reticulum ( $r E R$ ) is few and in the form of short cisternae. Some of the latter cisternae were observed in continuation with the outer nuclear membrane. Fat droplets (Fd) are also seen.

\section{Stratum intermedium (spinosum) (Fig. 2 a, b, c):}

The stratum intermedium consists of 15-17 layers of large polygonal cells which become slightly flattened towards the surface. They are connected together and with the neighbouring with interdigitations and numerous desmosomes(D) through their cytoplasmic projections which extend into the narrow intercellular space.

The spinous cells have large nuclei (N) which are rounded or ovoid in shape with few shallow indentations and or segmentations. The nuclei are central lylocated and have the same electron density of the cytoplasm. The heterochromatin is few and distributed as in the basal cells. They contain 1-2 large nucleolei (Nc). A well-defined many nuclear pores (P) interrupting the distinct nuclear envelope.

Assiut Vet. Med. J. Vol._29, No. 58, July, 1993. 
The cytoplasm of the deep cell layers of the Stratum spinosum is structurally similar to the basal cells while that of the upper layers contains fewer cytoplasmic organelles. The most characteristic feature of this stratum is the nembrane-coating granules which are firstly seen within the upper spinous cells in association with both Golgi complex (G) and the cytoplasmic filaments (F). Then after, they are scattered in the cytoplasm of the upper layers. Also, it has been observed that the intercellular spaces in this part of the Stratum spinosum contained material (arrowheads) apparently identical to the contents of these granules. There are dense filaments ( $F$ ) traversing the cytoplasm in different directions but do not form bundles as those observed in the Stratum basale.

3. Stratum granulosum (Fig. 3):

Inconstant thin stratum granulosum could beobserved consisting of 1-2 of somewhat flattened cell layers. They are connected with each other and with the neighbouring cells with short desmosomes (D) and interdigitations through short and few cytoplasmic processes which project into a very narrow intercellular spaces.

The cells contain small irregular shaped dense keratohyalin granules $(\mathrm{KH})$ among the dispersed filaments $(F)$ in the cytoplasm. Fat droplets (Fd) as well as some membranecoating granules are also seen.

4. Stratum corneum (Fig. $4 ; 5$ a, b, c):

The stratum corneum consists of 9-11 layers of somewhat flattened cells. The outer surface of some superficial cells have numerous cytoplasmic microprojections. The cells of the deep layers of this Stratum are still connected to each other with interdigitations and short desmosomes (D) through few and shortcytoplsmic processes which extend into narrow intercellular spaces. The latter spaces widen and also the plasma membrane become thick toward the luminal surface of the esophagus. In addition, the desmosomes become very few superficially and totally disappear as the uppermost layers appear to separate from the underlying cells and shed into the esophageal lumen (Lu).

A pyknotic dense nucleus $(N)$ with indistinct membrane is seen in some cells of the stratum corneum.

Generally, the cytoplasmic organelles become replaced by filaments (F). The latter appear dispersed or in the form of small dense bundles, giving the cytoplasm therefore a variable electron density. In addition, the surface cells also have dispersed filaments. Fat droplets (Fd), empty vacuoles and few

Assiut. Vet. Med. J. V1. 29, No. 58, July 1993. 
ELECTRON MICROSCOPY, ESOPHAGEAL EPITHELIUM \& FOWL

small keratohyalin granules $(\mathrm{KH})$ could be observed in some cells of the Stratum corneum

\section{DISCUSSION}

The present study revealed that the esophagus of the adult fowl is lined with incompletely keratinized stratified squamous epithelium similar to that mentioned by HODGES (1974). The same observation is also recorded in human and rat oral mucosa as well as in the human esophagus (SOGNNAES \& ALBRIGHT, 1958; MATOLTSY \& PARAKKAL, 1965; HASHIMOTO et al. 1966; MEYER et al., 1970 and BLOOM \& FAWCETT, 1986). The latter authors described that the incomplete keratinization is due to that the nuclei of the cells of the superficial layers shrink and become metabolically inert, but do not disappear, and the cell bodies do not reach the same degree of flatness as in the epidermis.

However, BARTHELS (1895); BROWNE (1922); KRAUSE (1922); CALHOUN (1954); TRAUTMAN \& FIEBIGER (1957); FARNER (1960); KROLLING (1960); SAJONSKI \& SMOLLICH (1972); MCLELLAND (1975); SCHUMMER (1977); SMOLLICH \& MICHEL (1985) and BACHA \& WOOD (1990) stated that, the lining epithelium of the fowl esophagus is of a nonkeratinized stratified squamous epithelium. On the contrary BRADLEY \& GRAHAME (1960); LIM \& LOW (1977); SCHWARZE \& SCHRODER (1985); MICHEL et al. (1986) and BANKS (1993) descibed that this epithelium is of a keratinized type.

In the present work the intercellular spaces of the fowl esophageal epithelium is usually narrow and become wide oniy when the cells are in the process of being slaughed similar to those described by PLACKOVA et al.(1971) in the human oral
mucosa.

The present investigation revealed that some superficial cells of the fowl esophagus are studded with numerous cytoplasmic microprojections while the others are free from them. However, HASHIMOTO et al. (1966) in human buccal mucosa, PARAKKAL (1975) in mice esophagus and WILKINSON et al. (1989) in canine oral keratinocytes stated that these microprrojections are numerous. While, PLACKOVA et al. (1971) in the human oral mucosa observed that the microvilli are sparse, shorter and thinner or are altogether absent.

Obtained results in this work revealed the presence of membrane-coating ggranules (MCG) in the esophageal epithelium of the fowl which simulate those described in keratinized epithelum (ODLAND, 1960; FREI \& SHELDON, 1961); ZELICKSON \& HARTMANN, 1962; FARBMAN, 1964; MATOLTSY \& PARAKKAL, 1965; HASHIMOTO et al et al., 1966; HAYWARD \& HACKEMANN, 1973; JUNQUEIRA \& CARNEIRO, 1983; and BLOOM \& FAWCETT, 1986) as well as in nonkeratimized type (SILVERMAN, 1967; SILVERMAN \& KERNS,

Assiut Vet. Med. J. Vol. 29, No. 58, July, 1993. 
1970; and HAYWARD \& HACKEMANN, 1973). In agreement with PARAKKAL, (1975) in mice esophagus these granules are fistly appeared in the upper spinous cells in association with Golgi complex and filaments, then they are scattared in the cytoplasm of the upper layers. However, in rat and human oral epithelium such association could not be observed (FARBMAN, 1964 and HAYWARD \& HACKEMANN, 1973)

In the epithelium of the fowl esophagus a substance apparently identical to the contents of the membrane-coating granules could be observed in the intercellular spaces. FARBMAN (1964) in rats oral epithelium, MATOLTSY and PARAKKAL (1965) in keratinized epithelium, HAYWARD and HACKEMANN (1973) in human oral epithelum, PARAKKAL (1975) in mice esophageal epithelium, MULLER and SCHRODER (1980) in human hard palate, JUNQUEIRA and CARNEIRO (1983) in human epidermis stated that the membranecoating granules (MCG) discharged their contents into the intercellular spaces and this substance spreads upon the cell membrane making it more thick. FARBMAN (1964) in rats oral epithelim, SQUIER and WATERHAUSE (1967), and JUNQUEIR and CARNEIRO (1983) in human skin mentioned that the membranecoating granules act as a barrier to the penetration of foreign materials across the epithelium and provides a very important sealing effect. However, HAYWARD and HACKEMANN (1973) in human oral epithelium suggested that the function of the granules vary with the degree of keratinization.

Our results revealed that the cytoplasmic filaments exist in a variable manner. Also, the surface cells have dispersed filaments as observed by WILKINSON et al.(1989) in canine oral mucosa.

The present work revealed that the epithelial cells of all strata of the fowl esophagus contain variable number of fat droplets as found in human oral mucosa (HASHIMOTO et al. , 1966; PLACKOVA et al., 1977), chick skin (MATOLTSY, 1969). However, MULLER and SCHROEDER (1980) observed that in human hard palate these droplets were first seen in the Stratum granulosum and become numerous in the Stratum corneum. They represent decomposed nucleus and synthetic organelles when the cells enter the horny stage (MATOLTSY, 1969: chick skin). Moreover, vacuoles are also observed in some cells of the Stratum corneum similar to that described by PLACKOVA et al (1971) in human oral mucosa.

Although, the present investigation revealed that the epithelium of the fowl esophagus is characterized by incompletekeratinization, irregular shaped keratohyalin granules are observed. These finding are in accordance with those

Assiut. Vet. Med. J. V1. 29, No. 58, July 1993. 
mentioned by JUNQUEIR and CARNEIOR (1983) in human vagina; $B L O O M$ and FAWCETT (1986) in human esophagus.

\section{REFERENCES}

Bacha, W.J. and Wood, L. M. (1990): Color atlas of Veterinary Histology. Lea \& Febiger, Philadelphia. London.

Banks, W.J. (1993): Applied veterinary histology. 3rd Ed. St. Louis Baltimore Boston Chicago London Philadelphia Sydney Toronto. Mosby.

Barthels, P. (1895): Beitrag zur Histologie des Osophagus der Vogel. Z. Schr. Wiss. Zool., 59: 655-689.

Bloom, W. and Fawcett, D.W. (1986): A textbook of histology. 11 th Ed. W. B. Saudners Comp. Philadelphia.

Bradley, O.C. and Grahame, T. (1960): The structure of the fowl. 4 th Ed. Oliver and Boyd, Edinburgh and London.

Browne, T.G. (1922): Some observations on the digestive system of the fowl. J. Comp. Path. therap., 35: 12-32.

Calhoun, M.L. (1954): Microscopic anatomy of the digestive system of the chicken. Ames, Iowa; Iowa state College Press.

Farbman, A.I. (1964): Electron microscope study of a small cytoplasmic structure in the rat oral epithelium. J. Cell. Biol., 21: 491-495.

Farner, D.S.(1960): Digestion and the digestive system. In biology and comparative physiology of birds. Acad. Press,
New York, London.. Vol 1.

Frei, J.V. and Sheldon, H. (1961): A small granular component of the cytoplasm of Keratinizing epithelia. J. Biophys. Biochem. Cytol., 11: 719-724.

Hashimoto, K,; Dibelila, R.J. and Shklar, G. (1966): Electron microscopic studies of the normal buccal mucosa. J. Investig. Derm., 47: 512-525.

Hayward, A.F. and Hackemann, M. (1973): Electron microscopy of membrane-coating granules and a cell surface coat in keratinized and non-keratinized human oral epithelium. J. Ultrast. Res., 43: 205-219.

Hodges, R.D. (1974): The histology of the fowl. Academic Press, London. New York. San Francisco.

Junqueira, L.C. Carneiro, J. (1983): Basic Histology. 4th Ed. Middle East Ed. Lange medical publications, Los Altos. California.

Krause, R. (1922): Mikroskopische Anatomie der wirbeltiere. II: der Vogel und Reptilien. Berlin and Leipzig, Vereingung Wissen Verlag; Walter de Gruyter and Co.

Krolling, 0 . (1960) In Lehrbuch der Histologie und vergleichenden mikroskopischen Anatomie der Haustiere. Von

Assiut Vet. Med. J. Vol. 29, No. 58, July, 1993. 
KROLLING, O. und H. Grau. 10 Aufl. Berlin, Hamburg, Paul Parey.

Lim, S.S. and Low, F.N. (1977): Scanning electron microscopy of the developing alimentary canall in the chick. Am. J. Anat., 150: 149-173.

Matoltsy, A.G. and Parakkal, P.F. (1965): Membrane-coating granules of Keratinizing epithelia. J. Cell Biol., 24: 297-307

Matoltsy, A.f. (1969): keratinization of the avian epidermis. An ultrastructural study of the newborn chick skin. J. Ultrastruct. Res., 29: 438-458.

McLelland, J. (1975): Aves digestive system: In the anatomy of the domestic animals. Rev. by R. Getty. 5th Ed. vol 2. W. B. Saunder Comp. Philadelphia. London. Toronto.

Mercer, E.H. (1961): Keratin and Keratinization. p. 231, Pergamon Press, New York.

Meyer, J., Alvares, O.F. and Barrington, E.P. (1970): Volume and dry weight of cells in the epithelium of rat cheek and palate. Growth, 34: 57-73.

Michel, G., Salomon, F.V. and Gutte, G. (1986): Besonderheiten des Verdauungssystems beim Geflugel. In; Morphologie Landwirtschaflicher Nutztiere.1 Aufl. Quelle and Meyer Heidelberg Wiesbaden

Muller, W. and Schroeder, H.E. (1980): Differentiation of the epithelium of the human hard palate. Cell Tissue Res., 209: 295-313.

Odland, G.F. (1960): A submicroscopic granular component in human epidermis. J. Inves. Dermatol., 34: 11-15.

Parakkal, P.F. (1975): An electron microscopic study of esophageal epithelium in the newborn and adult mouse. Am.

J. Anat., 121: 175-196.

Plackova, A., Medak, H., Meyer, J. and Waterhouse, J.P. (1971): Ultrastructure of surface cells of the oral mucosa. Folia Morphol., XIX: 165-170.

Sajonski, H. and Smollich, A. (1972): Verdauungssystem des Geflugels: In Mikroskopische Anatomie. S. Hirzel Verlag Leipzig.

Schummer, A. (1977): Anatomy of the domestic birds. Vol. V. Verlag Paul Parey, Berlin and Hamburg.

Schwarze, E. and Schroder, L. (1985): Die Verdauungsorgane. In: Kompendium der Geflugelanatomie. 4. Aufl. VEB Gustav Fischer Verlag Jena.

Silverman, S.J. (1967): Ultrastructure studies of oral mucosa.

1. Comparison of normal and hyperkeratotic human buccal epithelium. J. dent. Res., 46: 1433-1445.

Silverman, S.Jr. and Kearns, G. (1970): Ultrastructural

Assiut. Vet. Med. J. V1. 29, No. 58, July 1993. 
localization of acid phosphatase in human buccal epithelium. Archs. Oral Biol., 15: 169-177.

Smollich, A. and Michel, G. (1985): Verdauungssystem des Geflugels: In Mikroskopische Anatomie der Haustiere 1 Auf 1. VEB Gustav Fischer Verlag Jena.

Sognnaes, R.F. and Albright, J.T. (1958): Electron microscopy of the epithelial lining of the human oral mucosa. Oral Surg., Oral Med. and Oral Pathol., 11: 662-673.

Squier, C.A. and Waterhouse, J.P. (1967): Cited by Hayward and Hackemann (1973). In: Electron microscopy of membrane-coating granules and a cell surface coat in keratinized and nonkeratinized human oral epithelium. J. Ultrastruct. Res., 43: 205-219.

Trautmann, A. and Fiebiger, J. (1957): Fundamentals of the histology of domestic animals. Comstock Publishing Associates Ithaca, New York.

Wilkinson, J.E., Lee, C.S.,, Lillie, J.H., Suter, M.M. and Lewis, R.M. (1989): Ultrastructure of cultured canine oral keratinocytes. Am. . J. Vet. Res., 50; 1161-1165.

Zelickson, A.S. and Hartmann, J.F. (1962): An electron microscope study of normal human non-keratinizing oral mucosa. J. Invest. Derm., 38: 99- 106.

\section{LEGENDS}

Fig. $1 \mathrm{a}, \mathrm{b}$ : Electron micrograph of the basal cell layer of the esophageal epithelium of the fowl.

$N$ Nucleus; Nc Nucleolus; $P$ Pores; F Cytoplasmic filaments; M Mitochondria; rER Rough endoplasmic reticulum; Fd Fat droplets;

D Desmosomes; B1 Basal Iamina; HD Hemidesosomes (a X 5000; b X 10.000).

Fig. 2 a, b, c: Electron micrograph of the stratum spinosum of the esophageal epithelium of the fowl.

N Nucleus; Nc Nucleolus; P Pores; (arrows) Membrane-coating granules; which discharge their content in the intercellular spaces (arrowheads); G Golgi complex; F Cytoplasmic filaments; M Mitochondria; rER Rough endoplasmic reticulum; D Desmosomes (a X 8000 . b X 27.000; c X 20.000).

Fig. 3 : Electron micrograph of the stratum granulosum of the esophageal epithelium of the fowl.

$\mathrm{KH}$ Keratohyalin granules; F cytoplasmic filaments; Fd Fat droplets; D Desmosomes (X 10.000). 
Fig. 4/5 a, b, c: Electron micrograph of the stratum corneum of the esophageal epithelium of the fowl.

$\mathrm{N}$ pyknotic nucleus; $\mathrm{F}$ cytoplasmic filaments; Fd Fat droplets; KH Keratohyalin granules; Is Intercellular space; D Desmosomes; (arrows) microprojections; Lu Esophageal Lumen (4 X $4000 ; 5$ a X 27.000, b X 14.000; c X 8000).

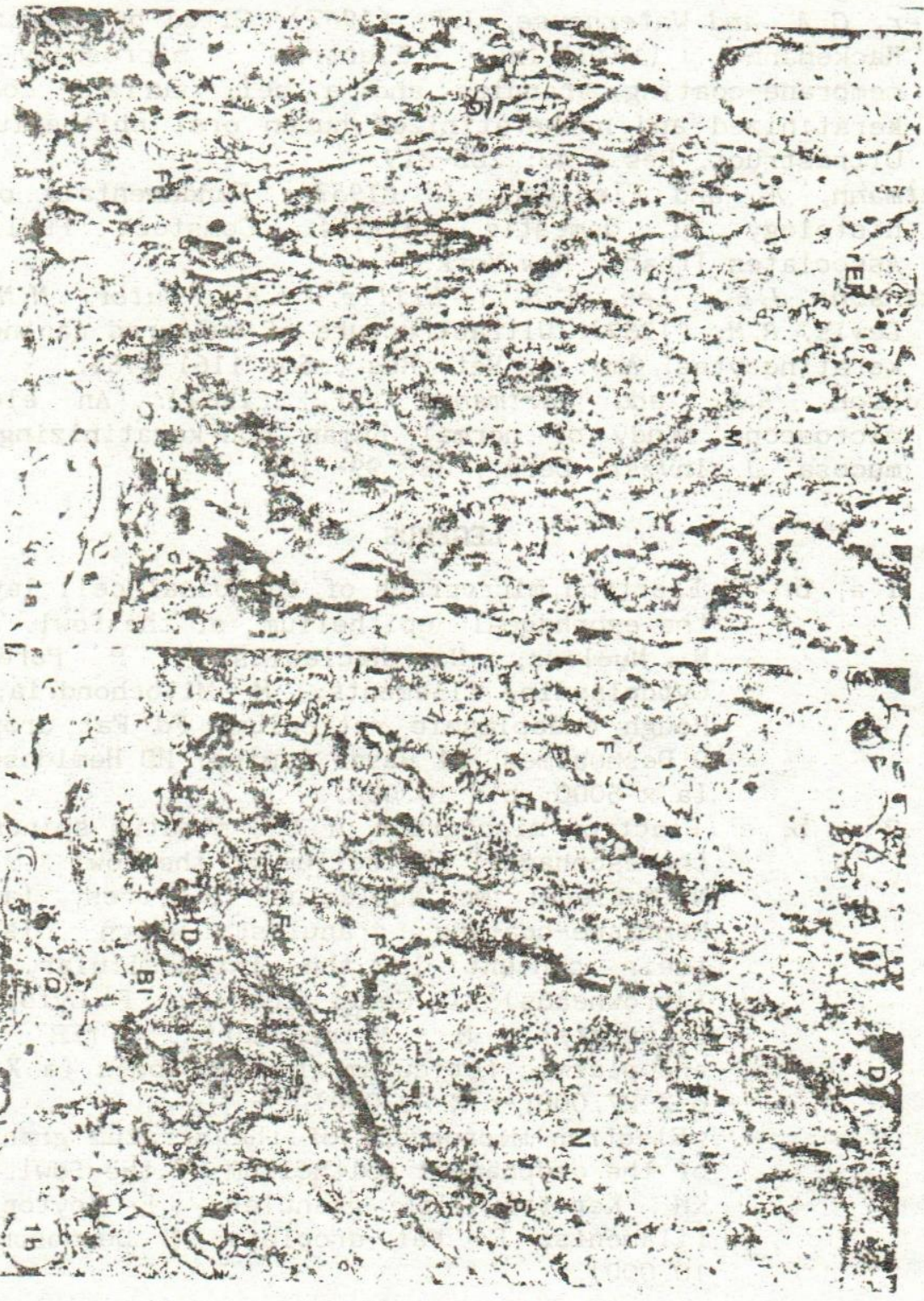

Assiut. Vet. Med. J. V1. 29, No. 58, Juiy. 1993. 


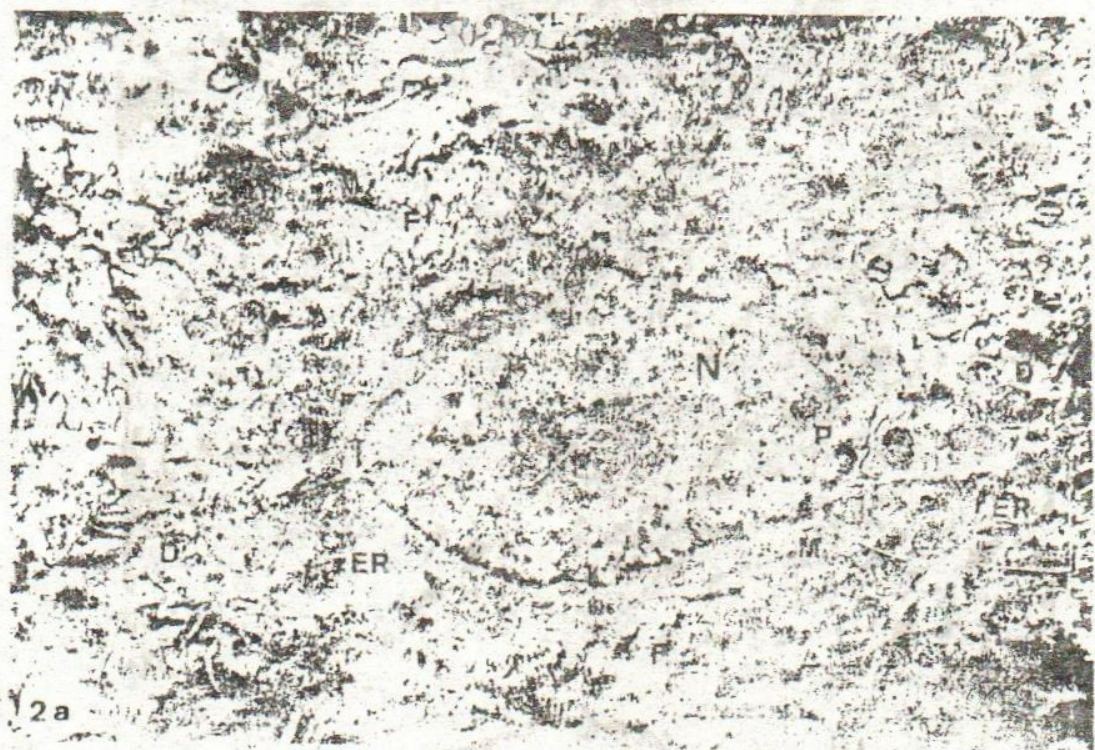

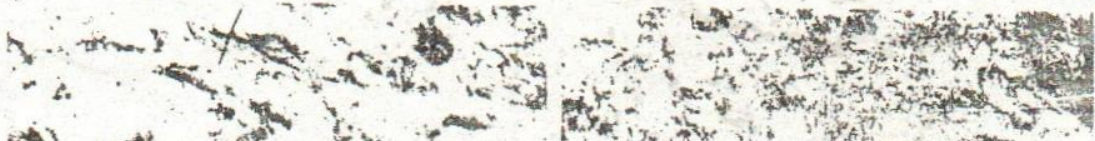

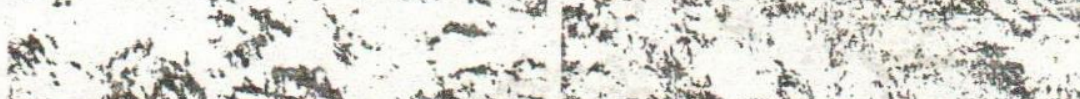

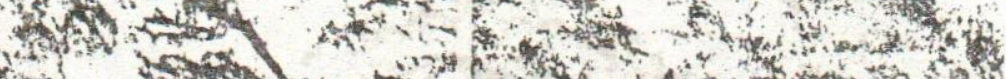

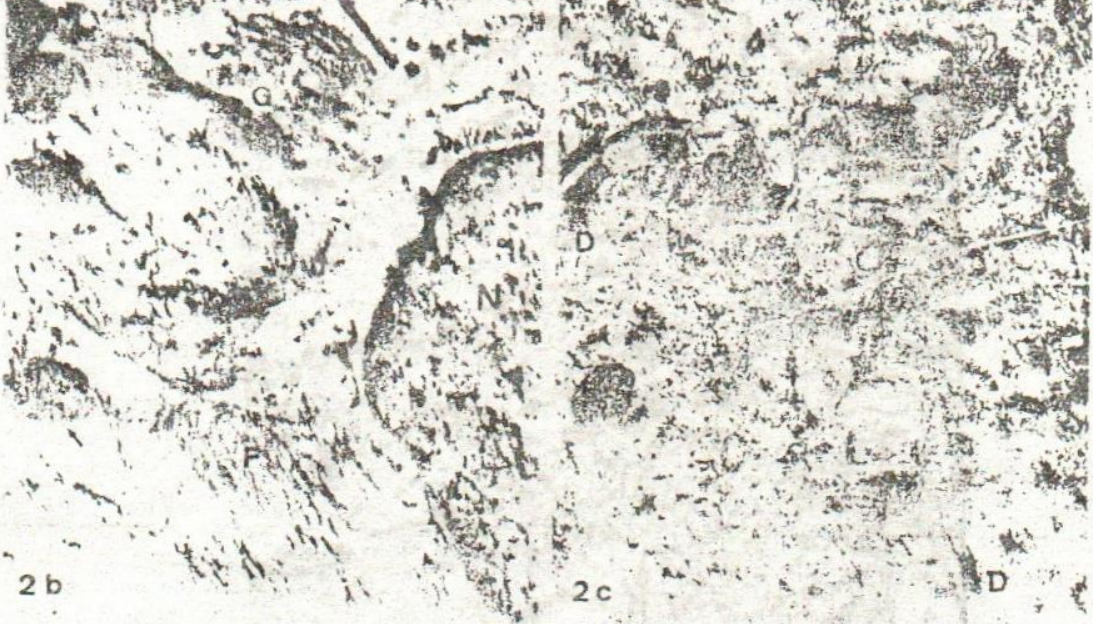



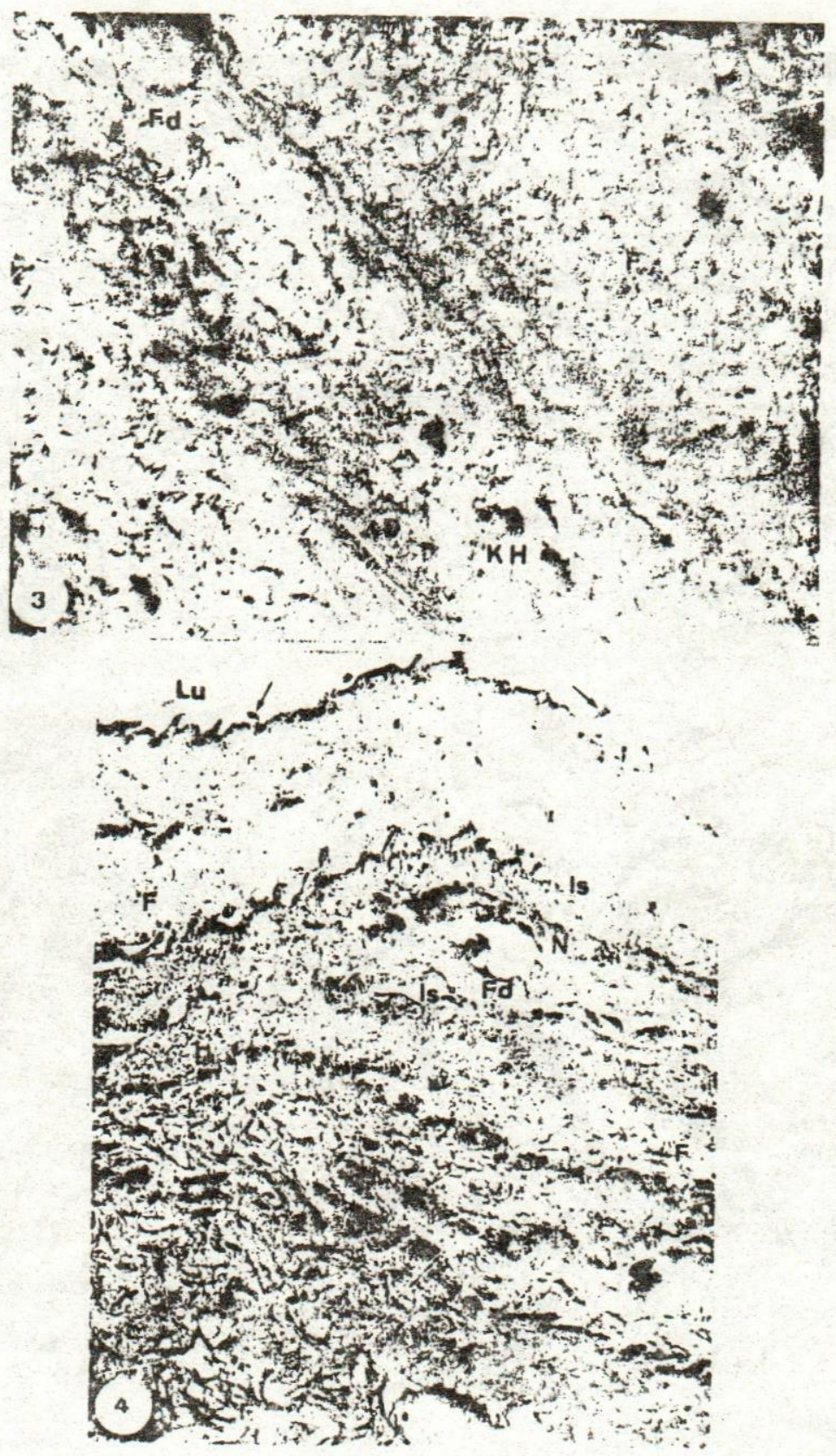


\section{ELECTRON MICROSCOPY, ESOPHAGEAL EPITHELIUM \& FOWL}

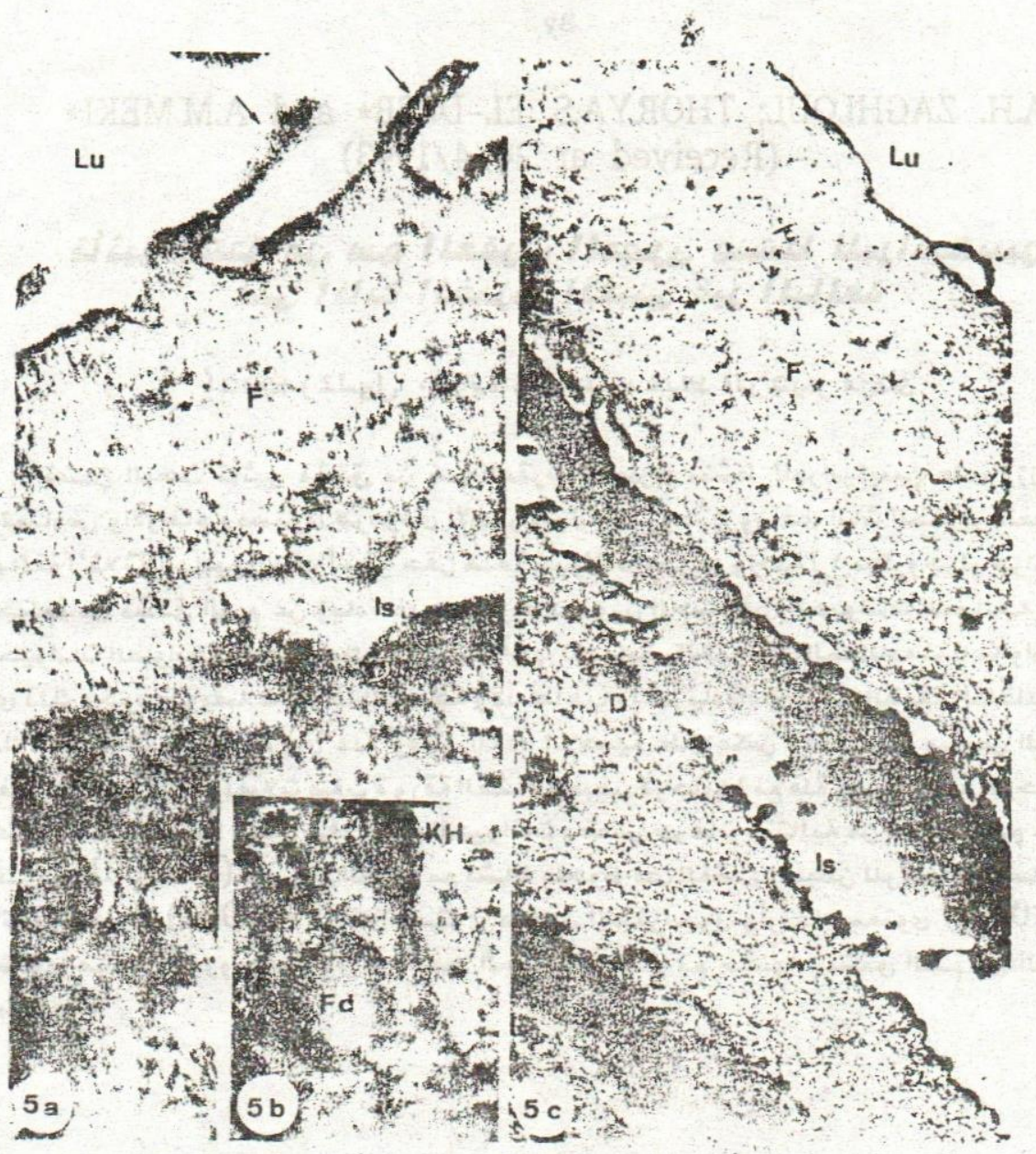

Assiut Vet. Med. J. Vol. 29, No. 58, July, 1993. 